\title{
Species introductions, diversity and disturbances in marine macrophyte assemblages of the northwestern Mediterranean Sea
}

\author{
Judith Klein*, Sandrine Ruitton, Marc Verlaque, Charles-François Boudouresque \\ UMR 6540, Centre d'Océanologie de Marseille, Université de la Méditerranée, Parc scientifique et technologique de Luminy, \\ 13288 Marseille cedex 9, France
}

\begin{abstract}
In the process of species introduction, the traits that enable a species to establish and spread in a new habitat, and the habitat characteristics that determine the susceptibility to introduced species play a major role. Among the habitat characteristics that render a habitat resistant or susceptible to introductions, species diversity and disturbance are believed to be the most important. It is generally assumed that high species richness renders a habitat resistant to introductions, while disturbances enhance their susceptibility. In the present study, these 2 hypotheses were tested on NW Mediterranean shallow subtidal macrophyte assemblages. Data collection was carried out in early summer 2002 on sub-horizontal rocky substrate at 9 sites along the French Mediterranean coast, 4 undisturbed and 5 highly disturbed. Disturbances include cargo, naval and passenger harbours, and industrial and urban pollution. Relationships between species richness (point diversity), disturbances and the number of introduced macrophytes were analysed. The following conclusions were drawn: (1) there is no relationship between species introductions, diversity and disturbance for the macrophyte assemblages; (2) multifactorial analyses only revealed the biogeographical relationships between the native flora of the sites.
\end{abstract}

KEY WORDS: Species introduction · Marine macrophytes · Point species diversity · Disturbances · France $\cdot$ Mediterranean Sea

\section{INTRODUCTION}

There is a wide range of possible effects resulting from the introduction of non-indigenous species. The introduced species may have negligible or little effect; however they may also become invasive species and alter the host ecosystem profoundly, with serious ecological and economic consequences (Carlton 1989, 1996a, Ribera \& Boudouresque 1995, Eno et al. 1997, Ivanov et al. 2000, Bax 2003). The rate of biological introductions of marine macrophytes into new areas of the world has been increasing dramatically over the last few decades (Ribera \& Boudouresque 1995). This is mainly due to an increase in ship traffic, aquaculture and other human activities, which multiply the opportunities for introduction (Carlton 1996b). It has been found, for several terrestrial ecosystems as well as for marine macrophytes in the Mediterranean Sea, that approximately 1 out of 10 introduced species (= established) becomes invasive in the new environment; this crude estimation is known as the 'tens rule' (Williamson 1993, Williamson \& Fitter 1996, Boudouresque \& Verlaque 2002a).

However, the factors determining whether the introduction of a new species is successful and whether acclimation takes place in the new habitat are poorly understood. Success will depend on the species' biological and physiological characteristics, the dispersion vectors, and the environmental characteristics of the host ecosystem (Ashton \& Mitchell 1989, Simberloff 1989, Ribera \& Boudouresque 1995, Goodwin et al. 1999). 
The environmental characteristics that render an environment or habitat vulnerable or resistant to biological introductions are currently the focus of much debate. Two of these characteristics, species richness and disturbance, have been extensively discussed (Simberloff 1989, Cohen \& Carlton 1998, Occhipinti Ambrogi 2000). The hypothesis known as Elton's 'biotic resistance hypothesis' (Elton 1958) assumes that a species-rich ecosystem will be more resistant to introductions than a species-poor one. Several researchers have found that there seems to be a negative correlation between species richness and the number of introduced species in a habitat (Loope \& Mueller-Dombois 1989, Pimm 1989, Rejmánek 1989, Simberloff 1989, Lodge 1993, Ribera \& Boudouresque 1995). This is usually explained by the fact that an ecosystem with many species represents a highly structured system with many complex inter-species interactions, such as competition, predation, mutualism, parasitism and disease. The higher the number of competitors, predators, parasites and diseases, the lower will be the availability of resources such as space, nutrients and light, and the possibility of successful establishment of introduced macrophytes (Stachowicz et al. 1999). However, as far as heterotrophic introduced organisms are concerned, the picture is more ambivalent, because a higher number of species will increase the diversity of biological resources and trophic niches potentially available to the introduced species. Oceanic islands, which have low species numbers and absence or quasi-absence of some taxonomic groups (e.g. mammals) or functional guilds (e.g. predatory or herbivorous mammals) have often been taken as examples to illustrate the devastating effects of species introductions on native communities (Stone et al. 1992, Fritts \& Rodda 1998, Thibault et al. 2002, Meyer et al. 2003). Such islands usually have simplified food webs and less inter-specific interaction compared to continental ecosystems, and species introductions are, for the most part, highly successful (MacArthur \& Wilson 1967, Loope \& Mueller-Dombois 1989). In other cases, the communities are vulnerable to biological introductions whatever the degree of species richness. Hence, according to Moyle \& Light (1996), freshwater fish assemblages in California are susceptible to introductions, regardless of the diversity of the resident fishes. A valuable parameter to consider is the study scale and the type of community. In the USA, Stohlgren et al. (1999) highlighted a negative correlation between native and introduced species richness at a $1 \mathrm{~m}^{2}$ scale and in some vegetation types, and a reverse relationship in other vegetation types and at landscape and biome scale.

Disturbances of the environment represent the second environmental characteristic that could play a major role in determining whether a community is rather vulnerable or resistant to species introductions (Hobbs 1989). High levels of disturbance favour species introductions by temporarily disrupting or depleting native communities (Moyle \& Light 1996). The quality, frequency and the degree of the disturbances have to be taken into account. It has been shown that there is a positive correlation between the frequency of the disturbance and the success of an introduced species (Ashton \& Mitchell 1989, Rejmánek 1989, Case 1996, Moyle \& Light 1996). The disturbances act differently within structured communities, either by increasing limiting resources (space, light and nutrients), or by determining the development of communities that are 'unsaturated' in terms of species numbers, or immature in terms of succession (communities poor in superior competitors). All these different kinds of disturbance lead to greater vulnerability of the community with respect to species introductions (Hobbs 1989, Pimm 1989). However, Connell's 'intermediate disturbance hypothesis' (Connell 1978) suggests that the degree of disturbance is important (in terms of intensity, frequency and efficiency) in determining the species richness of an ecosystem: the highest species diversity is reached at intermediate levels of disturbance; lower or higher levels of disturbance decrease species richness. Hence, man-made disturbances in urban areas can increase both native and introduced plant species richness (Stadler et al. 2000).

The Mediterranean is, at the world scale, the sea that harbours the greatest number of introduced macrophytes. However, like the Japanese temperate region and southern Australia, it is also a hot spot for macrophyte species diversity ( $\varepsilon$ species diversity sensu Gray 2000). This is not consistent with the assertion that high species diversity improves resistance to species introductions. The eastern Mediterranean basin has lower $\varepsilon$ species diversity (sensu Gray 2000) than the western basin, but harbours relatively more introduced species, most of which originate from the Red Sea (Lessepsian species). The great success of Lessepsian species in the eastern basin has been explained by the low native species diversity, and the resulting vacant niches and low inter-specific competition pressure (Boudouresque 1999). In the western Mediterranean, where there is an absence or quasi-absence of Lessepsian species, fewer vacant niches and higher diversity and inter-specific competition may prevent colonization; however, other factors such as temperature and currents may play an important role. It is worth noting that the number of introduced species via ship transport is higher in the western than in the eastern basin, despite its higher species diversity (Boudouresque \& Verlaque 2002b). In addition, pristine species-rich localities are now strongly affected by certain introduced species: the Corsica Nature Reserve 
of Scandola (France) (Rodriguez Prieto et al. 1993), the National Park of Port-Cros (France) (Thélin 1984 LEML-ENSA 2003, M. Verlaque unpubl. data), the Medes Islands (Spain) (Sala \& Boudouresque 1997), Gorgona Island (Italy) (Piazzi \& Cinelli 2001) and the Nature Reserves of Croatia (A. Zuljevic pers. comm.).

In the Mediterranean, certain disturbed environments exhibit higher numbers of introduced taxa than undisturbed ones (Galil 2000). It has been suggested that the success of 2 introduced Caulerpa species, $C$. racemosa var. cylindracea (hereafter, C. racemosa) and C. taxifolia, is linked to the degradation of the Posidonia oceanica (L.) Delile beds, due to direct or indirect human influence (Occhipinti-Ambrogi \& Savini 2003). In certain habitats that are exposed to human-made disturbances and which possess rather low species diversity, such as harbours and lagoons, the number of introduced species is higher than in undisturbed ones. However, all pathways of introduction converge in such habitats, so that the relationship between disturbance, low species diversity and high number of introduced species may be an artefact due to the high rate of species importation (Ribera \& Boudouresque 1995, Boudouresque \& Verlaque 2002b).

In the present study, 2 questions were approached: (1) Is there a negative correlation between species richness and number of introduced species? and (2) is the number of introduced species higher in a disturbed community than in an undisturbed one? Shallow subtidal assemblages of rocky substrate were selected, because they possess the highest species richness ( $\alpha$ species diversity sensu Gray 2000) among Mediterranean benthic communities (Coppejans 1980, Verlaque 1987, Ballesteros 1988, 1990, 1993).

\section{MATERIALS AND METHODS}

Study area. Data collection was carried out between June and July 2002 at 9 different sites along the French Mediterranean coast, from west to east: (1) Fos (F), (2) Sausset-les-Pins (S), (3) Marseille (M), (4) Riou (R), (5) Cortiou (Co), (6) Cassis (Ca), (7) Embiez (E), (8) Toulon (T) and (9) Hyères (H) (Fig. 1). Of the 9 sites, Sausset, Riou, Cassis and Embiez are considered to be little or not at all impacted by man-made disturbances (agricultural, urban and industrial pollution, harbour activities, aquaculture).

The other sites are considered as being disturbed. The Fos site lies on the SE coast of the Gulf of Fos, close to a major industrial area including a cargo harbour and an oil tanker terminal with petrochemical facilities. The Marseille site is located in the south of Marseille, a big city with a passenger and cargo harbour. The Cortiou site is in close vicinity (at a distance of approximately $500 \mathrm{~m}$ ) of the urban sewage outlet of the

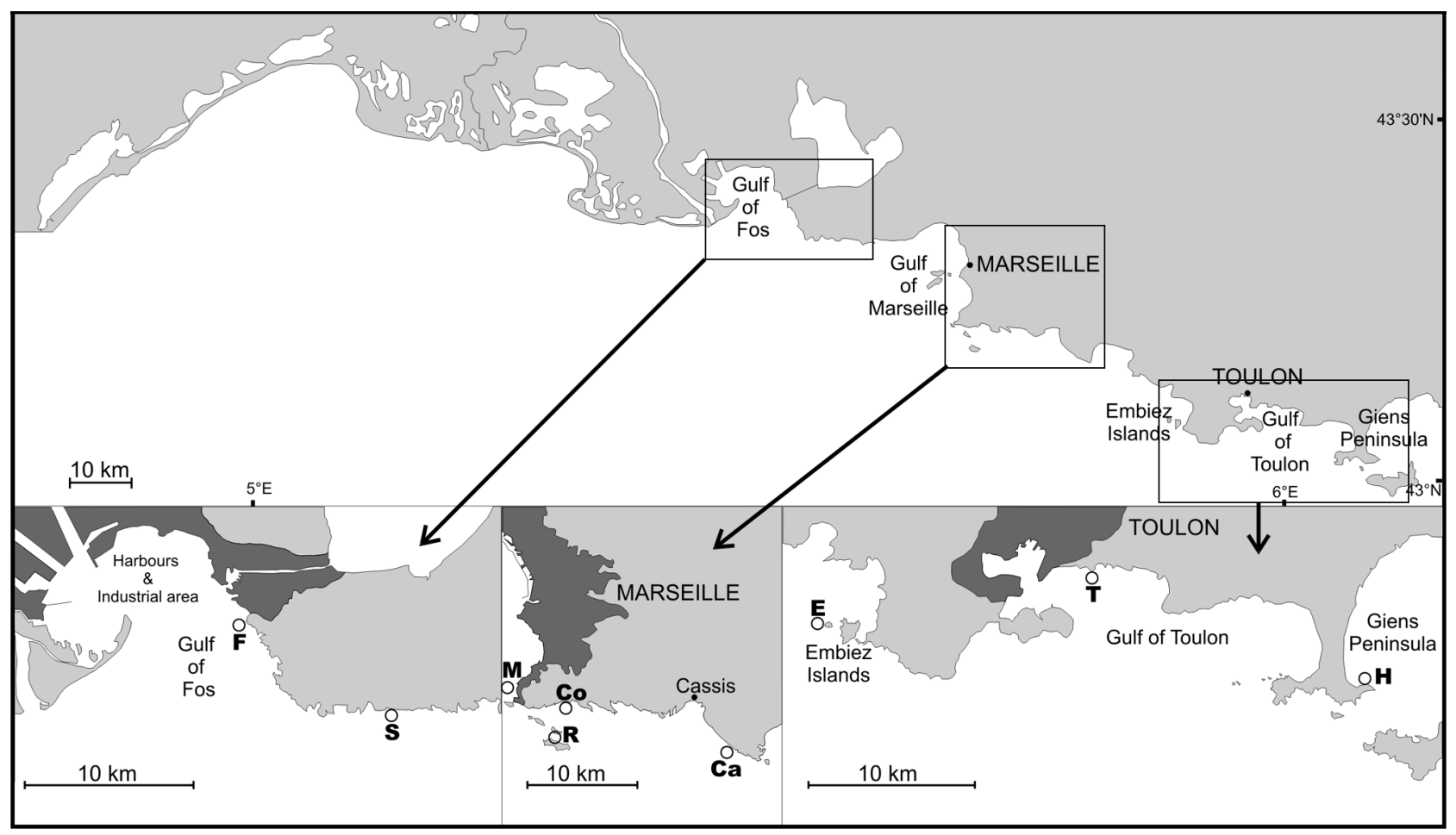

Fig. 1. Study sites. F: Fos; S: Sausset; M: Marseille; Co: Cortiou; R: Riou; Ca: Cassis; E: Embiez; T: Toulon; H: Hyères 
Marseille region, where effluents (ca. $270000 \mathrm{~m}^{3} \mathrm{~d}^{-1}$ ) have undergone secondary treatment since 1987 . The Toulon site is situated close to the Toulon naval and passenger harbour, which frequently accommodates foreign vessels. Finally, the Hyères site was chosen at the SE tip of the Giens Peninsula in a rocky area exposed to hyper-sedimentation and organic pollution. Although the evaluation of the levels of disturbance is qualitative, these 6 sites have been highly exposed to man-made disturbances for at least 50 to $100 \mathrm{yr}$.

A natural calcareous substrate characterizes all sites, except for Embiez and Hyères, where the substrate is siliceous. The shallow subtidal assemblages were sampled between 4 and $8 \mathrm{~m}$ depth.

Sampling of the macrophyte assemblages. In order to draw up an exhaustive list of native macrophytes per site (point species diversity sensu Gray 2000, hereafter species richness), six $50 \times 50 \mathrm{~cm}$ quadrats, randomly positioned on the sub-horizontal rocky substrate $\left(0\right.$ to $20^{\circ}$ ), were sampled by SCUBA diving along a $50 \mathrm{~m}$ transect. In each quadrat, all the macrophytes that could be identified in situ were recorded and a $15 \times 15 \mathrm{~cm}$ sub-sample was taken by scraping with hammer and chisel. Sub-samples were preserved in buffered $4 \%$ formaldehyde-seawater.

In the field, the percentage of surface covered by the 3 functional-form groups, defined according to Littler (1980) and Littler \& Arnold (1982), was estimated by means of a metal frame: (1) the encrusting group (prostrate encrusting forms), (2) the filamentous group (delicately branched, filamentous forms), and (3) the erect group, which includes 4 of Littler's functional-form groups: the sheet group (thin tubular and sheet-like, foliose forms), the coarsely branched group (coarsely branched, upright forms), the thick leathery group (thick blades and branches) and the jointed calcareous group (articulated, calcareous, upright forms).

Sample analysis. Fixed material was separated and identified using a binocular microscope and if necessary a light microscope. All macroscopic taxa belonging to the Chlorophyceae, Chrysophyceae, Phaeophyceae, Rhodophyceae and Tribophyceae were identified to species level and, for some small epiphytes, to genus level in order to complement the list established in situ. In the case of heteromorphic taxa, the different life-history phases (e.g. Falkenbergia phase) were taken into account. For taxonomic purposes, the database of Guiry \& Nic Dhonncha (2004) was chosen. The list of native macrophytes per site (hereafter, species richness) was established considering the cumulative data of the $50 \times 50 \mathrm{~cm}$ quadrats (samples and sub-samples).

Introduced macrophyte inventory. The list of introduced macrophytes per site was drawn up considering the species present in the $50 \times 50 \mathrm{~cm}$ quadrats comple- mented by those present along the $50 \mathrm{~m}$ transect, but not in the quadrats, to take into account the introduced species that are patchily distributed. The different phases of species possessing a heteromorphic life history were distinguished, because some of them are capable of persisting and spreading by vegetative multiplication or apomictic reproduction without phase alternance. The list of introduced macrophytes was established by using the checklists of Boudouresque \& Verlaque (2002a) and Wallentinus (2002). For each species, the most probable vector(s) of introduction are given: oyster transfers $(\mathrm{O})$, ship traffic including ballast water and fouling (ST), and aquarium trade (A). In the NW Mediterranean, Lessepsian migration (i.e. introduction of Red Sea species into the Mediterranean via the Suez Canal) plays a minor role in species introductions, due to the low probability of direct introduction from the Red Sea (necessity of secondary vectors: ship traffic or shellfish transfers) (Boudouresque 1999).

Data analysis. The relationships between species composition and the number of introduced species were analysed. Differences in the functional groups' percentage cover between sites were tested with the Student-Newman-Keuls (SNK) test, after a 1-way ANOVA and a test of the homogeneity of variances (Bartlett's test). A non-parametric Mann-Whitney $U$-test was used to detect significant differences in the number of native and introduced species between undisturbed and disturbed sites. A Correspondence Analysis (CA) (Greenacre 1984, Roux 1985) was carried out using the presence of native species at each site as input data, to describe floristic affinities between sites and to identify possible parameters involved (geographical and man-made disturbances). Following the $\mathrm{CA}$, an Ascendant Hierarchical Classification (AHC) analysis was performed in order to facilitate interpretation of the position of the sites in 3-dimensional space. Thereby, the coordinates of the sites on the first 3 axes of the CA (Roux 1985) were used as input data. The Hierarchical Classification used the Euclidean distance and the complete linkage clustering. All analyses were carried out using the Statistica 6 software ${ }^{\circledR}$.

\section{RESULTS}

\section{Native flora}

A total of 223 putative native taxa and life-history phases were identified in the $50 \times 50 \mathrm{~cm}$ quadrats (samples + sub-samples). The species richness per site (point diversity) ranged from 77 to 144 . As expected, the undisturbed sites possessed higher species richness than the disturbed ones (122 to 144 versus 77 to 129 taxa and phases) (Appendix 1; www.int-res.com/ 
journals/suppl/klein_appendix.pdf), although these differences were not significant (Mann-Whitney $U$ test, $\mathrm{p}=0.1111$ ). The highest and lowest species richness were found at the undisturbed site of Cassis (144) and at the disturbed site of Cortiou (77), respectively. The species richness of the 3 sites situated close to harbours (Fos, Marseille and Toulon: 126 to 129) was similar to that of the undisturbed sites (122 to 144), whereas that of the polluted sites of Cortiou (77) and Hyères (119) was lower (see Appendix 1).

The dominant group was the Rhodophyceae (46 to 102 species), followed by the Phaeophyceae (10 to 26 species) and Chlorophyceae (21 to 25 species) (Appendix 1). The frequencies of the classes were similar between undisturbed and disturbed sites, except for the site of Cortiou, which is highly impacted by freshwater and nutrient inputs, where an increase in the percentage of Chlorophyceae (27\%) was observed.

\section{Introduced flora}

A list of 15 macrophytes, 14 species and 1 life-history phase, regarded as introduced was established from the $50 \times 50 \mathrm{~cm}$ quadrat data (Table 1). Among the introduced species, Laurencia caduciramulosa was reported for the first time along the French Mediterranean coast (Klein \& Verlaque in press). Among the macrophytes growing along the $50 \mathrm{~m}$ transects but not in the quadrats, additional introduced species were found, most of them the disturbed sites (Table 1).

At the undisturbed sites, the analysis of the total introduced flora showed that the species belonged exclusively to the Rhodophyceae. In addition, 2 introduced Chlorophyceae occurred at the disturbed sites (Table 1). Ship traffic (14 species) is the most effective introduction vector, followed by oyster transfer (2 species), aquarium trade (2 species) and the Suez Canal (1 species); the total exceeds 15, because several vectors are possible for some species.

\section{Relationships between introduced macrophytes, species richness and disturbance}

In the quadrats, there was no relationship between the species richness and the number of introduced macrophytes (Fig. 2). Moreover, there was no significant differ-

Table 1. Introduced macrophytes at the sites (S: Sausset; R: Riou; Ca: Cassis; E: Embiez; F: Fos; M: Marseille; Co: Cortiou; T: Toulon; H: Hyères). +: present in samples; P: present along the transect; -: absent. Possible vectors of introduction: O: Oyster transfers; ST: Ship traffic; SC: Suez Canal; A: Aquarium trade (according to Verlaque 1994 and Ribera \& Boudouresque 1995 amended)

\begin{tabular}{|c|c|c|c|c|c|c|c|c|c|c|}
\hline & \multicolumn{4}{|c|}{ Undisturbed } & \multicolumn{5}{|c|}{ Disturbed } & \multirow[t]{2}{*}{ Vector } \\
\hline Locality: & $\mathrm{S}$ & $\mathrm{R}$ & $\mathrm{Ca}$ & $\mathrm{E}$ & $\mathrm{F}$ & $\mathrm{M}$ & $\mathrm{Co}$ & $\mathrm{T}$ & $\mathrm{H}$ & \\
\hline \multicolumn{11}{|l|}{ Rhodophyceae } \\
\hline Acrothamnion preissii (Sonder) E. M. Wollaston & - & - & - & + & - & - & - & - & + & ST \\
\hline Antithamnion amphigeneum Millar & - & - & - & - & - & + & - & - & - & ST \\
\hline \multicolumn{11}{|l|}{ Antithamnionella boergesenii (Corm. \& G. Furn.) } \\
\hline Athanasiadis & - & + & - & - & - & - & - & - & - & ST \\
\hline Apoglossum gregarium (Dawson) Wynne & - & - & - & - & - & - & - & - & $\mathrm{P}$ & ST \\
\hline Asparagopsis armata Harvey & + & + & + & _- & + & + & + & + & - & ST \\
\hline Chondria curvilineata Collins \& Hervey & - & _- & - & + & - & - & - & - & + & ST \\
\hline 'Falkenbergia rufolanosa' life-history phase & + & + & + & + & + & + & + & + & + & ST \\
\hline Goniotrichopsis sublittoralis G. M. Smith & - & - & - & - & - & - & - & - & + & ST \\
\hline Hypnea spinella (C. Agardh) Kützing & - & - & - & - & + & - & - & - & - & $\mathrm{ST} / \mathrm{SC}$ \\
\hline Laurencia caduciramulosa Masuda \& Kawaguchi & + & + & + & $\mathrm{P}$ & + & + & - & + & - & ST \\
\hline Polysiphonia atlantica Kapraun \& J. Norris & + & + & + & _- & + & - & + & - & - & $\mathrm{ST} / \mathrm{O}$ \\
\hline P. harveyi Bailey & + & + & + & + & + & + & + & + & + & $\mathrm{ST} / \mathrm{O}$ \\
\hline Womersleyella setacea (Hollenberg) R. E. Norris & + & + & + & + & + & + & - & + & + & $\mathrm{ST}$ \\
\hline Total & 6 & 7 & 6 & 6 & 7 & 6 & 4 & 5 & 7 & \\
\hline$\%$ & 100 & 100 & 100 & 100 & 100 & 85.7 & 100 & 71.4 & 77.8 & \\
\hline \multicolumn{11}{|l|}{ Chlorophyceae } \\
\hline \multicolumn{11}{|l|}{ Caulerpa racemosa var. cylindracea (Sonder) } \\
\hline Verlaque, Huisman et Boudouresque & - & _- & - & _- & - & $\mathrm{P}$ & - & $\mathrm{P}$ & $\mathrm{P}$ & ST/A \\
\hline C. taxifolia (Vahl) C. Agardh & - & - & - & - & - & - & - & $\mathrm{P}$ & $\mathrm{P}$ & A \\
\hline Total & 0 & 0 & 0 & 0 & 0 & 1 & 0 & 2 & 2 & \\
\hline$\%$ & 0 & 0 & 0 & 0 & 0 & 14.3 & 0 & 28.6 & 22.2 & \\
\hline Total in samples & 6 & 7 & 6 & 5 & 7 & 6 & 4 & 5 & 6 & \\
\hline Total at site & 6 & 7 & 6 & 6 & 7 & 7 & 4 & 7 & 9 & \\
\hline
\end{tabular}




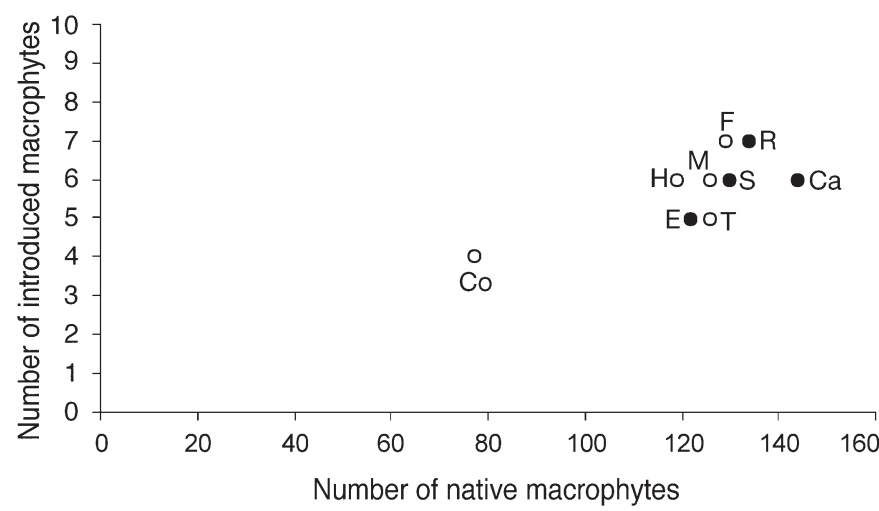

Fig. 2. Relationship between the number of macrophytes (taxa and life-history phases) of the introduced and native flora in the $50 \times 50 \mathrm{~cm}$ quadrats (- undisturbed sites; O: disturbed sites). See Fig. 1 for abbreviations

ence in the numbers of introduced macrophytes between disturbed (4 to 7) and undisturbed sites (5 to 7) (Mann-Whitney $U$-test, $\mathrm{p}=0.7302$ ). The only conspicous site was the disturbed site of Cortiou, where low species richness (77) was coupled with a low number of introduced macrophytes (4) (Fig. 2, Appendix 1, Table 1). Results did not change when introduced species present along transects were included.

\section{Structural organization of the macrophyte assemblages}

Considering both native and introduced macrophytes in the quadrats, all sites had a high total percentage cover (Fig. 3). The undisturbed sites showed macrophyte assemblages with high and rather stable percentages of the functional-form groups (encrusting, filamentous and erect groups). In contrast, at some of

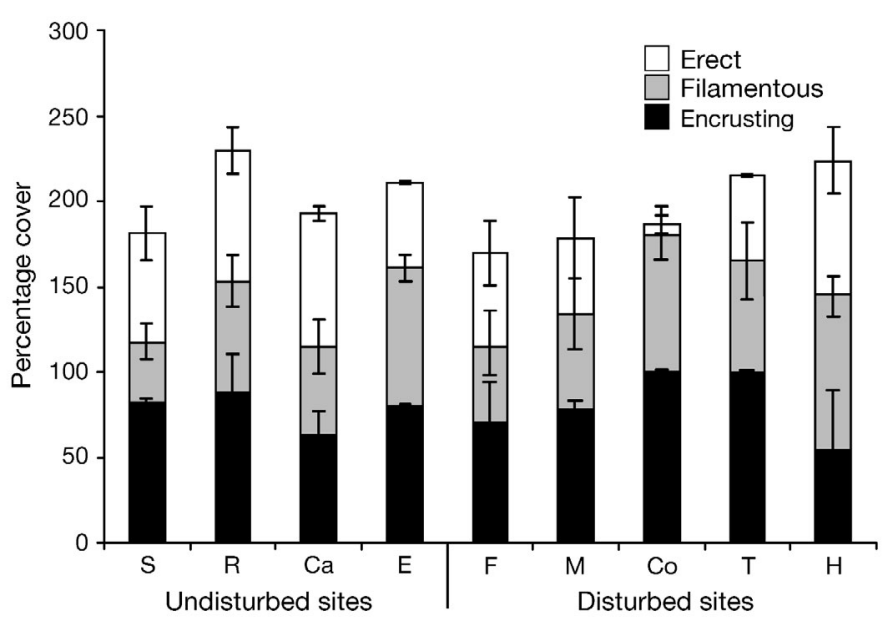

Fig. 3. Percentages of the different functional-form groups (encrusting, filamentous and erect group) in $50 \times 50 \mathrm{~cm}$ quadrats (mean, SD). See Fig. 1 for abbreviations the disturbed sites, the cover was more heterogeneous (Fig. 3). Thus, the erect macrophytes were very poorly represented at Cortiou (SNK test, $\mathrm{p}=0.0001$ ) (Fig. 3). There was no relationship between the structural organization (functional-form group composition) of the assemblage and the number of introduced macrophytes. Moreover, it should be noted that the macrophyte assemblage at Cortiou, with its poor representation of the erect group, possessed the lowest number of introduced macrophytes of all sites. The other sites possessed assemblages with high and rather stable percentages of the functional-form groups, and a number of introduced macrophytes ranging from 5 to 7 (Table 1).

\section{Ordination}

In the first $\mathrm{CA}$ of the native flora, there was an agglomeration of all sites close to the centre of gravity, except for Cortiou, which was positioned at the extreme end of Axis I (Fig. 4). This can be explained by the particular vegetation and/or very low species richness of Cortiou. This polarization rendered difficult interpretation of the relationships between the sites that were more similar in terms of species richness and composition. To further investigate the relationships between these sites, the CA was re-performed excluding Cortiou. In this second $\mathrm{CA}$, the distant position of Hyères on Axis I contrasted with the clustering of the other sites close to the center of gravity. Along Axis II, 2 groups can be distinguished, one including sites of eastern Provence and the other those of western Provence (Fig. 5).

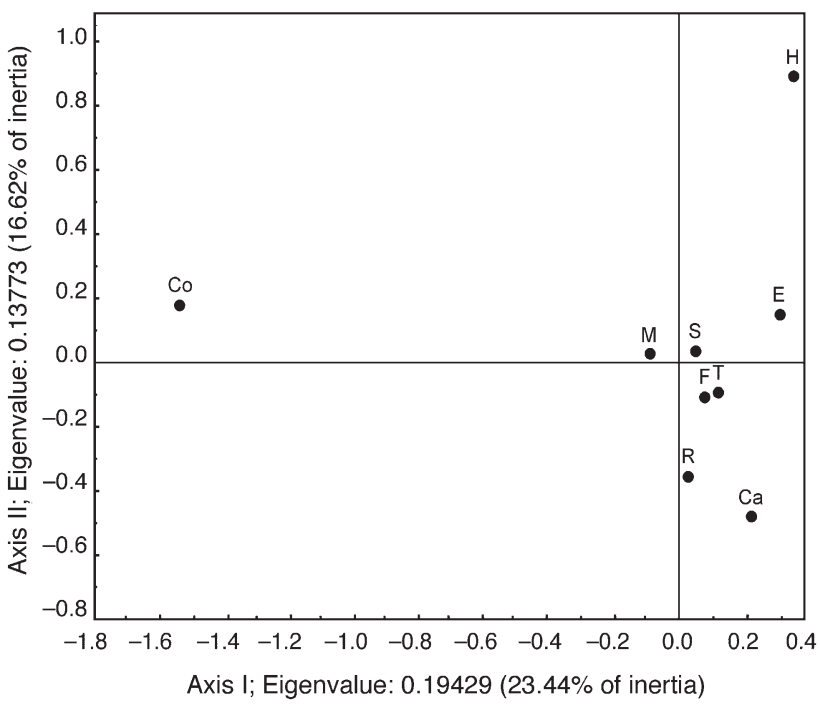

Fig. 4. Correspondence analysis of the native flora: Axes I and II of the first CA including all sites. See Fig. 1 for abbreviations 


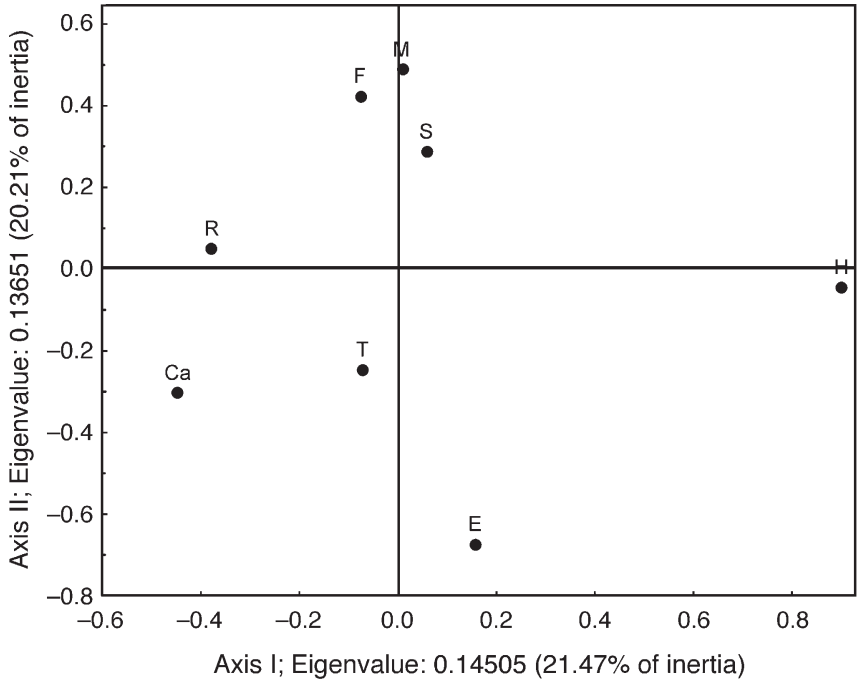

Fig. 5. Correspondence analysis of the native flora: Axes I and II of the second CA excluding Cortiou. See Fig. 1 for abbreviations

\section{Classification}

In the AHC using the coordinates of the sites on the first 3 axes of the second CA, 2 groups can be distinguished, one including the sites of eastern Provence (Toulon, Embiez and Hyères) and the other those of western Provence (Cassis, Riou, Marseille, Fos, Sausset) (Fig. 6).

In western Provence, characteristic taxa were: Aglaothamnion tripinnatum, Haraldia lenormandii, Leathesia mucosa, Lithophyllum dentatum, Phyllophora heredia, Pterosiphonia pinnulata, Radicilingua thysanorhizans and Seirospora giraudyi. Most of these species have cold-temperate affinities.

In eastern Provence, characteristic taxa were: Cystoseira brachycarpa, Dasycladus vermicularis, Dictyota linearis, Discosporangium mesarthrocarpum, Halopithys incurva, Jania adhaerens, Neurocaulon foliosum, Rytiphloea tinctoria and Pseudolithoderma adriaticum, most of which have southern affinities and characterize the thermophilous communities of the French Riviera and the central part of the western Mediterranean Sea (Verlaque 1987, Ballesteros 1990).

As a consequence, after the elimination of Cortiou, the classification showed the biogeographical contrast between the cold and the warm temperate western Mediterranean assemblages rather than species richness or disturbance.

\section{DISCUSSION}

The present study of the shallow subtidal assemblages in the French Mediterranean Sea shows that there is no

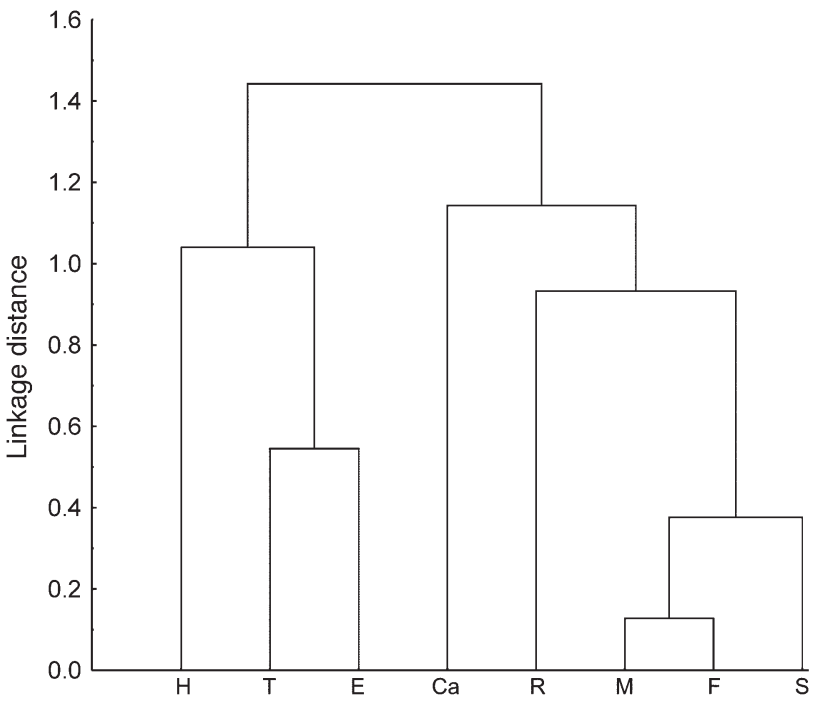

Fig. 6. Hierarchical Classification obtained with the coordinates of the sites on the first 3 axes of the second CA. See Fig. 1 for abbreviations

clear relationship between the species richness (point diversity sensu Gray 2000) and the number of introduced macrophytes. These findings stand in opposition to a long-believed theory that predicts that high species richness renders a habitat resistant towards species introductions (Elton 1958). Furthermore, the study reveals that there is no clear relationship between the number of introduced macrophytes and disturbances acting on the assemblages. At Cortiou, a highly disturbed site (Marseilles urban sewage outlet), low species richness is associated with the lowest number of introduced macrophytes of all sites. The ecological niches liberated by severe chemical and organic pollution and the subsequent decrease of inter-specific competition did not create an increase in the number of introduced species. The deleterious effects of the urban effluents act on native, as well as on introduced macrophytes.

As long as size, abundance and resource requirements are restricted (e.g. small Ceramiaceae or minute epiphytes such as Goniotrichopsis sublittoralis), the introduced marine macrophytes seem to be able to coexist with a rich native flora. On the other hand, the species exhibiting the most invasive behaviour (Acrothamnion preissii, Asparagopsis armata/Falkenbergia rufolanosa, Caulerpa racemosa, C. taxifolia and Womersleyella setacea) often overgrow the native communities (Verlaque \& Fritayre 1994, Piazzi et al. 2001). They possess high invasiveness (sensu Lonsdale 1999 and Alpert et al. 2000) due to one or several of the following physiological and/or behavioural advantages in comparison with most Mediterranean species: permanent populations, chemical defences, strong capacity for dispersal, prolific reproduction, wide ecological 
capacities, large size, faster growth (Ballesteros 1988, 1993, Boudouresque \& Verlaque 2002a). Native NW Mediterranean macrophyte species are characterized by miniaturization with respect to the Atlantic populations, as well as by seasonality of communities (Ballesteros 1988, 1991, 1993); therefore, invasive species colonize new areas regardless of the species richness. Their spread seems to be essentially dependent on the proximity of an introduction source, the size and type of the inoculum, the time elapsed since introduction, the existence of secondary vectors of diffusion, their capacity for reproduction, and ecological requirements. Hence, in Corsica and Sardinia, 2 little disturbed Mediterranean islands, no macrophyte species have been primarily introduced, whereas 9 species arrived there via secondary routes (Boudouresque \& Verlaque 2002b). Consequently, the absence of certain introduced species in some of our sites may be merely due to the short period of time elapsed since introduction and/or the absence of secondary vectors of spreading. Antithamnion amphigeneum, Apoglossum gregarium and Goniotrichopsis sublittoralis were only recently discovered along the French Riviera (1997/1998, Monaco, M. Verlaque unpubl. data) and seem to be in a spreading phase, much like Caulerpa racemosa and $C$. taxifolia, which were introduced less than 20 yr ago and whose remote spreading seems to be highly dependent on human activities (ship traffic, fishing) (Meinesz et al. 2001, Verlaque et al. 2004). Moreover, there is evidence that besides negative interactions (e.g. mutual exclusion) between 2 or more introduced taxa in the host ecosystem, the presence of 1 introduced taxon may enhance the success of another one and may, in this way, facilitate its establishment (Simberloff \& Von Holle 1999, Richardson et al. 2000). Hence, synergistic mechanisms have been observed between Caulerpa racemosa, Acrothamnion preissii and Womersleyella setacea, the latter 2 enhancing the growth and spreading of Caulerpa (Ceccherelli et al. 2002, Piazzi et al. 2003, E. Ballesteros unpubl. data).

Finally, each generation of scientists assumes a baseline condition of the ecosystem (stock size, species composition, abiotic properties) to be natural or pristine; this baseline is used in order to evaluate changes and to compare ecosystems. However, with time, this baseline is gradually drifting away from its original state (shifting baseline syndrome); the consequence is the utilisation of inappropriate reference points (Pauly 1995, Sheppard 1995, Tegner \& Dayton 1997). In most areas of the world, in order to understand underlying processes, ecologists are indeed studying highly degraded ecosystems (Jackson 1997). As far as the disturbances are concerned, in the NW Mediterranean Sea, where coastal ecosystems have been suffering from the deleterious consequences of anthropogenic activities (coastal development, agricultural, industrial and urban activities, ship traffic, tourism, aquaculture, fishing, over-exploitation and cascade effects) for a long time, are there still undisturbed communities? In many regions, species and communities have experienced a dramatic decline over the past decades (Posidonia oceanica meadows, Cystoseira spp. forests, certain coastal detritic communities such as maerl beds) (Boudouresque et al. 2004). Hence, the communities of our undisturbed sites may be very far from their original condition before human influence. Consequently, the very high rate of introductions in the Mediterranean and the great success of introduced macrophytes along the French coast may result from man-made changes to the coastal environment over several decades.

The present study is based on qualitative data (presence/absence), and it would be useful to consider species abundances. The quantitative composition of the host communities may influence the success of introduced species through biological relationships, such as competition, predation and parasitism. Moreover, the successional state (degree of maturity) or age of a community plays an important role in the vulnerability to species introductions as well (Crawley 1989). Certain successionally advanced communities are more resistant to species introductions than younger ones, although species richness may decline during the course of succession (Rejmánek 1989, Meiners et al. 2002, Sax 2002). As far as disturbances are concerned, their effects may vary according to their nature (chemical, physical or biological disturbances), history, frequency and intensity. In conclusion, the estimation of the vulnerability of Mediterranean macrophyte assemblages to species introductions requires consideration of quantitative data and comparison between similar sites in terms of environmental conditions, maturity of the assemblages (successional stage), disturbance and proximity to a potential introduction source. In addition, experiments where the frequency, degree and/or type of disturbance are controlled (e.g. control of sedimentation stress) could shed further light on the issue.

Acknowledgements. This work was supported by ALIENS ('Algal Introductions to European Shores'), a 5th Framework Programme of the European Union, and by grants from the Conseil Général 13, the Ville de Marseille and the Agence de l'Eau Rhône-Méditerranée-Corse. We would like to thank the anonymous referees for useful comments on the manuscript. We are indebted to M. Perret-Boudouresque for bibliographical assistance and M. Paul for reviewing the English text.

\section{LITERATURE CITED}

Alpert P, Bone E, Holzapfel C (2000) Invasiveness, invasibility and the role of environmental stress in the spread of nonnative plants. Perspect Plant Ecol Evol Syst 3:52-66 
Ashton PJ, Mitchell DS (1989) Aquatic plants: patterns and modes of invasion, attributes of invading species and assessment of control programmes. In: Drake JA, Mooney HA, Di Castri F, Groves RH, Kruger FJ, Rejmánek M, Williamson M (eds) Biological invasions: a global perspective. Scientific Committee on Problems of the Environment (SCOPE), Chichester, p 61-75

Ballesteros E (1988) Estructura y dinámica de la comunidad infralitoral de Codium vermilara (Olivi) Delle Chiaje de la Costa Brava (Mediterráneo occidental). An Biol 15 (Biología Ambiental 4):191-208

Ballesteros E (1990) Structure and dynamics of the Cystoseira caespitosa Sauvageau (Fucales, Phaeophyceae) community in the North-Western Mediterranean. Sci Mar 54: 155-168

Ballesteros E (1991) Structure and dynamics of north-western Mediterranean phytobenthic communities: a conceptual model. Oecol Aquat 10:223-242

Ballesteros E (1993) Species composition and structure of a photophilic algal community dominated by Halopteris scoparia (L.) Sauvageau from the North-Western Mediterranean. Collect Botan (Barcelona) 22:5-24

Bax N (2003) Marine invasive alien species: a threat to global biodiversity. Mar Policy 27:313-323

Boudouresque CF (1999) 14. The Red Sea-Mediterranean link: unwanted effects of canals. In: Sandlund OT, Schei PJ, Viken A (eds) Invasive species and biodiversity management. Kluwer Academic Publisher, Dordrecht, p 213-228

Boudouresque CF, Verlaque M (2002a) Biological pollution in the Mediterranean Sea: invasive versus introduced macrophytes. Mar Pollut Bull 44:32-38

Boudouresque CF, Verlaque M (2002b) Assessing scale and impact of ship-transported alien macrophytes in the Mediterranean Sea. In: Commission Internationale pour l'Exploration Scientifique de la Mer Méditerranée (ed) Alien marine organisms introduced by ships in the Mediterranean and Black Seas. CIESM Workshop Monographs, Monaco 20:53-61

Boudouresque CF, Ruitton S, Verlaque M (2004) Anthropogenic impacts on marine vegetation in the Mediterranean. In: United Nations Environmental Programme (ed) Proc 2nd Mediterranean Symp on Marine Vegetation, Athens, 12-13 December 2003 (in press)

Carlton JT (1989) Man's role in changing the face of the ocean: biological invasions and implications for conservation of nearshore environments. Conserv Biol 3:265-273

Carlton JT (1996a) Pattern, process, and prediction in marine invasion ecology. Biol Conserv 78:97-106

Carlton JT (1996b) Marine bioinvasions: the alteration of marine ecosystems by nonindigenous species. Oceanography 9:36-43

Case TJ (1996) Global patterns in the establishment and distribution of exotic birds. Biol Conserv 78:69-96

Ceccherelli G, Piazzi L, Balata D (2002) Spread of introduced Caulerpa species in macroalgal habitats. J Exp Mar Biol Ecol 280:1-11

Cohen AN, Carlton JT (1998) Accelerating invasion rate in a highly invaded estuary. Science 279:555-558

Connell JH (1978) Diversity in tropical rain forests and coral reefs. Science 199:1304-1310

Coppejans E (1980) Phytosociological studies on Mediterranean algal vegetation: rocky surfaces of the photophilic infralittoral zone. In: Price JH, Irvine DE, Farnham WF (eds) The shore environment. Vol 2: Ecosystems. Systematics Association, Spec. Vol 17(a), Academic Press, London, p 371-393
Crawley MJ (1989) Chance and timing in biological invasions. In: Drake JA, Mooney HA, Di Castri F, Groves RH, Kruger FJ, Rejmánek M, Williamson M (eds) Biological invasions: a global perspective. Scientific Committee on Problems of the Environment (SCOPE), Chichester, p 407-423

Elton CS (1958) The ecology of invasions by animals and plants. Methuen, London

Eno NC, Clarck RA, Sanderson WG (1997) Non-native marine species in British waters: a review and directory. Joint Nature Conservation Committee, Peterborough

Fritts TH, Rodda GH (1998) The role of introduced species in the degradation of island ecosystems: a case history of Guam. Annu Rev Ecol Syst 29:113-140

Galil BS (2000) A sea under siege-alien species in the Mediterranean. Biol Invasions 2:177-186

Goodwin BJ, McAllister AJ, Fahrig L (1999) Predicting invasiveness of plant species based on biological information. Conserv Biol 13:422-426

Gray JS (2000) The measurement of species diversity: an example from the continental shelf of Norway. J Exp Mar Biol Ecol 250:23-49

Greenacre MJ (1984) Theory and application of correspondence analysis. Academic Press, London

Guiry MD, Nic Dhonncha E (2004) AlgaeBase version 2.0. World-wide electronic publication, National University of Ireland, Galway. http://www.algaebase.org (20.ii.2004)

Hobbs RJ (1989) The nature and effects of disturbance relative to invasions. In: Drake JA, Mooney HA, Di Castri F, Groves RH, Kruger FJ, Rejmánek M, Williamson M (eds) Biological invasions: a global perspective. Scientific Committee on Problems of the Environment (SCOPE), Chichester, p 389-405

Ivanov VP, Kamakin AM, Ushivtzev VB, Shiganova T, and 5 others (2000) Invasion of the Caspian Sea by the comb jellyfish Mnemiopsis leidyi (Ctenophora). Biol Invasions 2: $255-258$

Jackson JBC (1997) Reefs since Columbus. Coral Reefs 16:S23-S32

Klein J, Verlaque M (in press) Laurencia caduciramulosa Masuda et Kawaguchi (Ceramiales, Rhodophyceae), first record on the Mediterranean coast of France. Cryptogam Algol

LEML-ENSA (2003) Web site Caulerpa on line. http:// www.unice.fr/LEML/PageStatiques/CaulStart.html (20.ii. 2004)

Littler MM (1980) Morphological form and photosynthetic performances of marine macroalgae: tests of a functional/form hypothesis. Bot Mar 22:161-165

Littler MM, Arnold KE (1982) Primary productivity of marine macroalgal functional-form groups from southwestern North America. J Phycol 118:307-311

Lodge DM (1993) Biological invasions: lessons for ecology. Trends Ecol Evol 8:133-137

Lonsdale WM (1999) Global patterns of plant invasions and the concept of invasibility. Ecology 80:1522-1536

Loope LL, Mueller-Dombois D (1989) Characteristics of invaded islands, with special reference to Hawaii. In: Drake JA, Mooney HA, Di Castri F, Groves RH, Kruger FJ, Rejmánek M, Williamson M (eds) Biological invasions: a global perspective. Scientific Committee on Problems of the Environment (SCOPE), Chichester, p 257-280

MacArthur RH, Wilson EO (1967) The theory of island biogeography. Princeton University Press, Princeton, NJ

Meiners SJ, Pickett STA, Cadenasso ML (2002) Exotic plant invasions over 40 years of field succession: community patterns and associations. Ecography 25:215-223

Meinesz A, Belsher T, Thibaut T, Antolic B and 18 others 
(2001) The introduced green alga Caulerpa taxifolia continues to spread in the Mediterranean. Biol Invasions 3: 201-210

Meyer JY, Florence J, Tchung V (2003) Les Psychotria (Rubiacées) endémiques de Tahiti (Polynésie Française) menacés par l'invasion de Miconia calvescens (Melastomatacees): statut, répartition, écologie, phénologie et protection. Rev Ecol 58:161-185

Moyle PB, Light T (1996) Fish invasions in California: do abiotic factors determine success? Ecology 77:1666-1670

Occhipinti Ambrogi A (2000) Biotic invasions in a Mediterranean lagoon. Biol Invasions 2:165-176

Occhipinti Ambrogi A, Savini D (2003) Biological invasions as a component of global change in stressed marine ecosystems. Mar Pollut Bull 46:542-551

Pauly D (1995) Anecdotes and the shifting baseline syndrome of fisheries. Trends Ecol Evol 10:430

Piazzi L, Cinelli F (2001) Distribution and dominance of two introduced turf-forming macroalgae on the coast of Tuscany, Italy, Northwestern Mediterranean Sea in relation to different habitats and sedimentation. Bot Mar 44: $509-520$

Piazzi L, Ceccherelli G, Cinelli F (2001) Threat to macroalgal diversity: effects of the introduced green alga Caulerpa racemosa in the Mediterranean. Mar Ecol Prog Ser 210: 149-159

Piazzi L, Ceccherelli G, Balata D, Cinelli F (2003) Early patterns of Caulerpa racemosa recovery in the Mediterranean Sea: the influence of algal turfs. J Mar Biol Assoc UK 83:27-29

Pimm SL (1989) Theories of predicting success and impact of introduced species. In: Drake JA, Mooney HA, Di Castri F, Groves RH, Kruger FJ, Rejmánek M, Williamson M (eds) Biological invasions: a global perspective. Scientific Committee on Problems of the Environment (SCOPE), Chichester, p 351-367

Rejmánek M (1989) Invasibility of plant communities. In: Drake JA, Mooney HA, Di Castri F, Groves RH, Kruger FJ, Rejmánek M, Williamson M (eds) Biological invasions: a global perspective. Scientific Committee on Problems of the Environment (SCOPE), Chichester, p 369-388

Ribera MA, Boudouresque CF (1995) Introduced marine plants, with special reference to macroalgae: mechanisms and impact. Prog Phycol Res 11:187-268

Richardson DM, Pyšek P, Rejmánek M, Barbour MG, Panetta FD, West CJ (2000) Naturalization and invasion of alien plants: concepts and definitions. Diversity Distrib 6:93-107

Rodríguez Prieto C, Boudouresque CF, Marcot Coqueugniot J (1993) Nouvelles observations sur les algues marines du Parc Naturel régional de Corse. Trav Sci Parc Nat Rég Réserv Nat Corse, 41:53-61

Roux M (1985) Algorithmes de classification, méthode et programmes. Masson, Paris

Sala E, Boudouresque CF (1997) The role of fishes in the organization of a Mediterranean sublittoral community. I. Algal communities. J Exp Mar Biol Ecol 212:25-44

Sax DF (2002) Native and naturalized plant diversity are positively correlated in scrub communities of California and Chile. Diversity Distrib 8:193-210

Sheppard C (1995) The shifting baseline syndrome. Mar

Editorial responsibility: Otto Kinne (Editor-in-Chief), Oldendorf/Luhe, Germany
Pollut Bull 30:766-767

Simberloff D (1989) Which insect introductions succeed and which fail? In: Drake JA, Mooney HA, Di Castri F, Groves RH, Kruger FJ, Rejmánek M, Williamson M (eds) Biological invasions: a global perspective. Scientific Committee on Problems of the Environment (SCOPE), Chichester, p 61-75

Simberloff D, Von Holle B (1999) Positive interactions on nonindigenous species: invasional meltdown? Biol Invasions $1: 21-32$

Stachowicz JJ, Whitlatch RB, Osman RW (1999) Species diversity and invasion resistance in a marine ecosystem. Science 286:1577-1579

Stadler J, Trefflich A, Klotz S, Brandl R (2000) Exotic plant species invade diversity hot spots, the naturalized flora of northwestern Kenya. Ecography 23:169-176

Stohlgren TJ, Binkley D, Chong GW, Kalkhan MA and 6 others (1999) Exotic plant species invade hot spots of native plant diversity. Ecol Monogr 69:25-46

Stone CP, Smith CW, Tunison JT (1992) Alien plant invasions in native ecosystems of Hawaii: management and research. University of Hawaii Press, Honolulu, HI

Tegner MJ, Dayton PK (1997) Shifting baselines and the problem of reduced expectations in nearshore fisheries. American Society of Civil Engineers (ed) Proc Conf California and the World Ocean '97. San Diego, p 119-128

Thélin I (1984) Nouvelle signalisation d'Acrothamnion preissii (Sonder) Wollaston sur les côtes françaises de Méditerranée. Trav Sci Parc Nat Port-Cros 10:171-172

Thibault JP, Martin JL, Penloup A, Meyer JY (2002) Understanding the decline and extinction of monarchs (Aves) in Polynesian islands. Biol Conserv 108(2):161-174

Verlaque M (1987) Contribution à l'étude du phytobenthos d'un écosystème photophile thermophile marin en Méditerranée occidentale. Etude structurale et dynamique du phytobenthos et analyse des relations fauneflore. Thèse Scientifique, Université Aix-Marseille II, Marseille

Verlaque M (1994) Inventaire des plantes introduites en Méditerranée: origines et répercussions sur l'environnement et les activités humaines. Oceanol Acta 17:1-23

Verlaque M, Fritayre P (1994) Modifications des communautés algales méditerranéennes en presence de l'algue envahissante Caulerpa taxifolia (Vahl) C. Agardh. Oceanol Acta 17:659-672

Verlaque M, Afonso-Carrillo J, Gil-Rodriguez MC, Durand C, Boudouresque CF, Le Parco Y (2004) Blitzkrieg in a marine invasion: Caulerpa racemosa var. cylindracea (Bryopsidales, Chlorophyta) reaches the Canary Islands (NE Atlantic). Biol Invasions 6:269-281

Wallentinus I (2002) Introduced marine algae and vascular plants in European aquatic environments. In: Leppäkoski E, Gollash S, Olenin S (eds) Invasive aquatic species of Europe. Distribution, impacts and management. Kluwer Academic Publishers, Dordrecht, p 27-52

Williamson $M$ (1993) Invaders, weeds and the risk from genetically modified organisms. Experientia 49:219-224

Williamson M, Fitter A (1996) The varying success of invaders. Ecology 77:1661-1666

Submitted: June 15, 2004; Accepted: November 16, 2004 Proofs received from author(s): March 18, 2005 